9.

\title{
MAGAZIN SJEVERNE DALMACIJE I \\ DESNIČINA POLITIKA KNJIŽEVNOSTI: \\ NEKOLIKO NAPOMENA
}

\section{Vladimir Gvozden}

UDK: 050.8(497.581=163.41)“1934/35“

Izvorni znanstveni članak

Sažetak: Predmet članka je uočavanje dubinskih veza između Desničinog rada na uređivanju Magazina Sjeverne Dalamacije i njegovog literarnog opusa, naročito romana Zimsko ljetovanje i Proljeća Ivana Galeba. Delo Vladana Desnice pripada iskustvu rascepa i to rascepa koji potiče kako od modernističke ideje književnosti i pisanja kao nadređenog, višeg oblika egzistencije, tako i od samog fatuma koji je donelo rođenje na prostorima promenljive geografije, u Zadru, gradu koji se u 20. veku obreo u nekoliko država. Fractura tamnog/svetlog, nepoznatog/poznatog, naprednog/zaostalog, ta težnja da se preko dvojnosti - kroz izrazitu samosvest o podvojenosti - proširi vlastita egzistencija i njen smisao kod Desnice se širi, metastazira u raznim pravcima. Organizacija časopisa svakako je bliža prosvetiteljskoj ideji „mapiranja“ sveta nego savremenim radikalnim avangardnim časopisima koji su ispunjavali evropski kulturni prostor. Vladan Desnica bi se mogao svrstati u tabor arrière-gardes pa je iz toga ugla - a ne samo iz ugla nužnih ili svojevoljno prihvaćenih političkih kompromisa potrebno posmatrati i njegov rad na uređivanju Magazina Sjeverene Dalmacije. Iznad svega, taj rad je neophodno kontekstualizovati unutar Desničine politike književnosti (u smislu koji joj je dao Jacques Rancière), a ne unutar imaginarne političke istorije u kojoj je pisac svesno igrao sporednu ulogu.

Ključne reči: politika književnosti, estetizam, rasijalizam, regionalni identitet, egalitarizam, elitizam, arrière-gardes, podvojenost

D elo Vladana Desnice pripada iskustvu rascepa i to rascepa koji potiče kako od modernističke ideje književnosti i pisanja kao nadređenog, višeg oblika egzistencije, tako i od samog fatuma koji je donelo rođenje na prostorima promenljive geografije, u Zadru, gradu koji se u 20. veku obreo u nekoliko država. Rođen je u mestu na imaginarnoj granici, u mestu susreta, gde podvojenost biva poetizovana kao omen suprotstavljenih uticaja - blaga mediteranska klima/opora balkanska realnost, prisustvo/odsustvo, domaće/strano. Takva poetizacija egzistencije uistinu obeležava njegovo pisanje i predstavlja elementarni doživljaj sveta. U njegovom najpoznatijem delu, u Proljećima Ivana Galeba, pripovedač odmah na početku insistira na podvojenosti, u opisu kuće u kojoj je odrastao: 
Mogu reći da sam djetinjstvo proveo u tom hodniku gdje se bio vječiti boj između svjetlosti i sjene, između Arimana i Ahuramazde. Odatle mi je, možda, ostala za čitav život ta vječita dvojnost, ta osnovna podjela svega u životu i svijetu na zonu svjetlosti i na zonu mraka. ${ }^{1}$

Ova fractura tamnog/svetlog, nepoznatog/poznatog, naprednog/zaostalog, ta težnja da se preko dvojnosti - kroz izrazitu samosvest o podvojenosti - proširi vlastita egzistencija i njen smisao kod Desnice se širi, metastazira u raznim pravcima. Uslov njenog širenja je govorenje „da“ egzistenciji uz punu svest da se ona odvija na ivici ambisa. Svest o međusobno negirajućim stavovima o svetu i njegovoj istini gradi stubove suprotnih naboja, prostor nagomilanog potencijala. ${ }^{2}$ Ali taj prostor nije stabilan koliko se čini, jer ono što je svetlo i mediteransko može da zadobija tamne tonove, a čvrste opozicije, kao u romanu Zimsko ljetovanje, postaju fluidne, teško uhvatljive, nedovršive.

Zato je, uprkos kulturno-političkoj orijentaciji časopisa, važno Desničino uređivanje Magazina Sjeverne Dalmacije osmotriti kao njegovu poetičku delatnost, poetičku delatnost u onom smislu kako Dragan Jeremić tvrdi da ju je pisac sam odredio u jednom dijalogu sa njim:

Velite da pomalo apsolutizujem vrijednost poetskog u mom djelu. No možda se razilazimo samo in terminus, ne u smislu: pod poetskim ne mislim na poetično, već izrazima poetsko i poezija naprosto označavam svaku pravu estetsku umjetničku vrijednost, pa i sasvim „nepoetične " produkte. ${ }^{3}$

Dakle, i „nepoetični“ proizvodi mogu biti estetski - to je stav koji pisca približava temeljnom problemu modernizma: kako praviti umetnost od banalnosti života, kako pomiriti umetnost i svakodnevicu. Desničina verzija estetizma, ma koliko kritička bila, zaslužuje temeljno čitanje, ali je za sada potrebno reći da je njegovo insistiranje na tome da umetnost mora da se suoči sa podvojenostima kao takvim, a ne da stvara lažno jedinstvo povezana sa važnošću nalaženja odgovarajućeg izraza u cilju dolaženja do istine. Ovo je pozicija slična protomodernistima poput jednog Flauberta. Stoga ne čudi što će Desnica drugde izjaviti: „Larpurlartizam samo ponavlja grubu grešku sociologizma, na koji inače upravlja svoje strijele: i jedan i drugi nalaze svrhu umjetnosti u nečem različitom od njene prave svrhe: gole ljudske istine.“ Zanimljivo je što se, unutar estetskog režima (Jacques Rancière) ${ }^{4}$ do gole ljudske istine, dolazi posredno, putem rada na jeziku, putem konstrukcije, dakle književnosti.

Jer, ako je „gola ljudska istina“, kao što biva, veoma složen koncept, onda književnost kao čovekova jezička i intelektualna delatnost jeste ta koja joj se najviše može približiti. Ovo je piščeva utopija, vera ili možda čak i etička tvrdnja, koja računa sa izvesnom bezazlenošću fikcionalnih u odnosu na stvarnosne činove, ali počiva i na dubljim idejama ranih roman-

\footnotetext{
Vladan Desnica, Proljeća Ivana Galeba, u: Vladan Desnica (prir. Željko Milanović), Novi Sad 2013., 119.

Uporedi Dragan Jeremić, „Vladan Desnica“, Vladan Desnica (prir. Željko Milanović), Novi Sad 2013., 412.

Isto, 409.

4 Jacques Rancière, La parole muette: Essais sur les contradictions de la littérature, Paris 1998. Videti i njegove knjige Politika književnosti (Novi Sad, 2008) i Estezis: scene estetskog režima umetnosti (Novi Sad, 2014).
} 
tičara vezanim za njihovu reakciju na Kantovu filozofiju koja je utvrdila granice uma u odnosu na jezik i čulnost. U Desničinoj politici književnosti pravo pisanje učestvuje u raspodeli naših čulnih doživljaja, naših predstava u svetu ispunjenom viškom ljudi i stvari, u kojem je sve teže naći bilo kakvu izvesnost i utemeljiti sopstvenu egzistenciju kao valjanu. "Gola" istina bi bila ona istina koja nije proizvod lako predstavljive borbe; dakle možda je bolje reći ogoljena istina, istina lišena nanosa interpretacija i ideologija. Čini se da je iz ovog ugla utopijske potrage za "golom ljudskom istinom“ potrebno posmatrati i Desničin rad na uređivanju Magazina Sjeverne Dalmacije.

U stvari, čini se da je upravo iz ovog ugla potrebno čitati i napomenu koju nalazimo u prvom broju:

Nije namjera ovog Magazina da istakne i nametne neku svoju ideologiju i svoj program; on hoće samo da bude slobodan izraz težnja i ideja ovoga kraja i njegovih ljudi. Dosljedno tome, uredništvo je smatralo za potrebito da saradnicima ostavi najširu slobodu i punu odgovornost, kako u formalnom pogledu narječja, pravopisa i pisma, tako i u materijalnom pogledu idejnog sadržaja. ${ }^{5}$

Ovo je jednostavan stav i moglo bi mu se zameriti da je isuviše načelan, te da bi teško izdržao savremene skeptične primedbe o nemogućnosti bega od ideologije, o krizi reprezentativnosti, o nemogućoj neposrednosti izraza, o nezasnovanosti prozirnog odnosa jezika i želje. Pa ipak, činjenica je da se i ovde, uprkos svim nanosima opštih mesta, tvrdi da je ,gola ljudska istina" pluralna. Ono što je omogućilo ovakav gest je, razume se, usmerenost na regionalni identitet, koji se i inače najčešće ne gradi kroz tipičan, nasilan proces izgradnje nacije (nation-building), gde se celokupna populacija svodi na isto narečje, na isti pravopis, iste ideologije i programe. Regionalni identitet je identitet ljudi jednoga kraja, bivanje zajedno u istoj sredini - istorija je pokazala da je ova forma identiteta krhka i teško održiva. Za Desnicu zajednica je više od pukog sabiranja njenih članova, a u njegovoj perspektivi upravo taj višak bi trebalo Severnu Dalmaciju u teškom istorijskom trenutku da pretvori u političku jedinicu koja bi bila kadra da se izbori sa krupnim izazovima dezintegracije. Naime, Zadar kao grad koji je povezivao raznolike političke, ekonomske i kulturne sile ovog simboličkog prostora pripao je Italiji Rapalskim sporazumom iz 1920. Magazin Sjeverne Dalmacije je jedno od pisanih svedočanstava o političkom i ljudskom obigravanju oko ove praznine.

Nasuprot politici nejednakosti, sliku ovih prostora kakvu želi da predoči časopis, Desnica uspostavlja kao činjenicu prava jednog regiona, koja nisu ništa manja no što ih imaju drugi regioni: „Život ovoga kraja, njegove potrebe i njegove duhovne težnje, bar u principu, jednako su važni kao i život, potrebe i težnje ma kojeg drugog kraja. Ali su one, iz raznih uzroka, manje vidne i manje uvažavane."6 Savremenim rečnikom rečeno: Vladan Desnica se Magazinom Sjeverne Dalmacije bori za političku vidljivost njenih žitelja - odnosno imaginarne skupine u čije ime govori - unutar arene borbe za raspodelu čulnosti koja je isto-

5 Magazin Sjeverne Dalmacije, 1/1934., 2.

6 Isto, 3. 


\section{С А Д Р Ж А J}

Мирко Королија: Уводни сонет

Историја:

Бошко Десница: Неколико прилога историјском проучавању народне пјесме . . 7

» » Вук Мандушић . . . . . . . . . . . . . . . . . 25

$»$ \емунички догађај ....... . . . . . . . . . . . 31

» \ Смрт Стојана Јанковића и сеоба рамских фрањеваца у Далмацију 36

Др. Никола Суботић: Владика Симеон Кончаревић и вегов Летопис . . . . . 43

Ljubo Vlačić: Nekoliko dokumenata iz doba prvog i drugog pokušaja unijaćenja pravoslavnih u Dalmaciji . . . . . . . . . . . . . 53

» \ Izvještaj rimokatoličkog sveštenika Devića o stanju u Bosni u prvof polini XIX veka . . . . . . . . . . 80

Кв и жевност :

Мирко Колорија: Манастир Крка (пјесма) . . . . . . . . . . . . . . 87

Владан Десница: Двије импресије из Горње Далмације (пјесме) Сељани . . . . 88

Дјевојке на води . 88

» " Љетни мотив (пјесма) . . . . . . . . . . . . . . . 89

Ћиро Чичин-Шајин: Иницијали (пјесма) . . . . . . . . . . . . . . . 90

$\gg$ Коло (пјесма) . . . . . . . . . . . . . . . . 90

Мирко Колорија: Водопад Манојловац . . . . . . . . . . . . . . . 91

Ђиро Чичин-Шајин: Сјеверодалматински пејсажи . . . . . . . . . . . 95

Владимир Ризмондо: Грађанска Далмација у умјетности Симе Матавуља . . . 105

Владан Десница: Један поглед на личност Доситејеву . . . . . . . . . . 110

Културна и социјална питањ :

Др. Урош Десница: Југословенство као народност . . . . . . . . . . . 127

Др. Еуген Нежић: Маларија у Сјеверној Далмацији . . . . . . . . . . . 136

Dr. Stevo Metličić: Topografski nazivi u zadarskoj luci i okolo nje . . . . . 148

Др. Душан Урукало: Поморство и поморци Морлачког Канала . . . . . . . 155

Sl. 1. Sadržaj prvog broja Magazina Sjeverne Dalmacije (1934.)

vremeno podela moći. Političko je borba nevidljivih da budu viđeni, a potom i priznati (u hegelovsko-honetovskom smislu) prihvaćeni kao politički subjekti sa legitimnim ciljevima i težnjama. To je njihova „gola ljudska istina“. Reklo bi se da „gola“ u ovom kontekstu zapravo znači prećutana ili zapretena. No moramo imati na umu da, retorički posmatrano, Desnica nastupa previše načelno, što se iščitava iz sintagme $u$ principu, jer Magazin se očigledno ne zalaže za konkretnu političku akciju, već isključivo za pokušaj da se politika vodi sredstvima kulture. (Pitanje reprezentativnosti tekstova i autora zaslužuje zasebnu diskusiju, koja bi se mogla baviti Desničinom politikom; naravno, ukoliko je ova uopšte bitna osim kao politika književnosti.)

Bilo kako bilo, u uvodnom tekstu iz 1934. godine, odmah na njegovom početku, Desnica se nada izgradnji jednog političkog prostora za zajednicu. Taj prostor je javni život, 


\section{С А Д Р Ж А J}

Краљу Александру Првоме .

Lucijan Marcicic: Uzroci slabog ekonomsko-kulturnog razvoja zadarskog zaleđa . . 5

Lucijan Marčić: O nošnji na zadarskim i šibenskim ostrvima . . . . . . 15

Boško Desnica: Jedan krajiški štatut i nekoliko priloga za proučavanje »lige« . . 23

Бошхо Деснщща: Једна непозната буна и један незнани мученик . . . . . 47

Др. Јелха Перић: Шибеник у млетачко-турским ратовима (до 1671 г.) . . . 58

Марко Јежина: Шибеник у култури 15 вијека . . . . . . . . . 71

Dr. Dragan Plamenac: Šibenčanin Ivan Lukačić i njegovi moteti . . . . . 80

Dr. Grga Novak: Poziv Obrovca za slavenstvo Dalmacije . . . . . . . 87

Dr. Petar Kolendić: Zadranin Šimun Kožičić i njegova štamparija na Rijeci . . . 95

N. van Wijk: Рукописни патерик манастира Крке . . . . . . . . 108

Владимир Ризмондо: За једну далматинску културну оријентацију . . . . 111

Владан Десния: Мирко Королија и његов крај . . . . . . . . . . . 117

Мирко Королија: Зое Порфирогенета, драмски поем, І чин . . . . . . . . 131

Мирхо Королија: Четири посмртна сонета:

Ново пролеће - Осмех - Љубавни псалам - Источник . . 153

Владан Деснича: Животна стаза Јандрије Кутлаче, скица за роман . . . . 155

Чи т у љ а :

Др. Урош Деснища: † Др. Душан Баљак . . . . . . . . . . . . . . 174

Sl. 2. Sadržaj drugog broja Magazina Sjeverne Dalmacije (1935.)

čiju tradiciju on želi da oživi časopisom Magazin Sjeverne Dalmacije. Ovakvo razumevanje uloge časopisa svakako je primerenije 19. veku nego međuratnom razdoblju kada su časopisi, naročito oni umetnički i kulturni, sve više postajali izraz protesta, pobune, radikalnosti, odnosno artikulacije parcijalnih interesa onih koji nisu lako dolazili do istinske političke artikulacije. Časopis je, za Vladana Desnicu, uvek jednim svojim delom žanr prosvećenosti, stoga ne treba da čudi što kroz priloge provejava optimizam. Već na koncu kratkog, uvodnog teksta, on zapisuje: „Vršenje ovih zadataka zadovoljiće duhovne potrebe jednoga kraja, a i za cjelinu će značiti nesumnjivu dobit. "7 Implikujući veze između znanja i moći, Magazin je uključivao radove iz različitih oblasti, podeljene u broju iz 1934. u tri skupine: istorija, književnost, kulturna i socijalna pitanja. U broju iz 1935 . nema podele po rubrikama, ali su takođe prisutni radovi iz pomenutih širih oblasti. U užem smislu, u pitanju su radovi iz istoriografije, geografije, socijalne medicine, ekonomije, kao i književni prilozi, koji su bili najzastupljeniji. Ovakva organizacija časopisa svakako je bliža prosvetiteljskoj ideji „mapiranja“ sveta nego savremenim radikalnim avangardnim časopisima koji su ispunjavali evropski kulturni prostor. 
Svoju knjigu o književnim grupama, Vincent Kaufmann započinje rečima: „Dvadese-

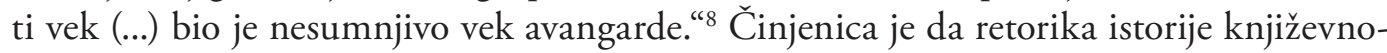
sti više naglašava nastanak neke pojave, a ne njeno trajanje. U studiji „Dvadeseti vek: vek pozadinaca?" William Marx ukazuje na to da su u 20. veku postojale arrière-gardes, što je francuski izraz, poput avangarde, preuzet iz vojne terminologije i označava pozadinske jedinice. On ukazuje da ovaj termin nije nužno sinonim za reakcionarnu estetiku, već da je potrebno razmisliti o dve kategorije umetnika koji se mogu svrstati u ovaj tabor: prva kategorija obuhvata kvalitativnu „pozadinu“, ili arrière-gardes, i označava grupu učaurenu u zastareli estetski pokret što ne znači da oni sami ranije nisu bili označeni kao avangarda; druga kategorija odnosi se na apsolutnu arrière-garde i uključuje one autore i autorke koji svesno i namerno biraju da gledaju u književnu i umetničku prošlost. ' Utisak je da bi se Vladan Desnica mogao svrstati u ovaj tabor, pa je iz tog ugla - a ne samo iz ugla nužnih ili svojevoljno prihvaćenih političkih kompromisa - potrebno posmatrati i njegov rad na uređivanju Magazina Sjeverene Dalmacije.

Potrebno je sprovesti neku vrstu strukturalne analize kako bi se dedukovala slika Severne Dalmacije. U časopisu je ona zaista višeslojna i dovoljno složena, jer je sagledana, kako je Desnica i predviđao, iz različitih uglova, bez ideje unapred uspostavljene saglasnosti povodom načina prikazivanja i ideološke interpretacije ovog regiona. Potrebno je takođe razlučiti koji iskazi spadaju u specifične iskaze o Severnoj Dalmaciji, a koji iskazi su deo širih diskurzivnih poredaka. Moguće je najpre govoriti o nekoliko načelnih teza koje Magazin Sjeverne Dalmacije izlaže: narod sa ovih prostora je istorijski narod kako iz razloga političke i vojne istorije (uskoci, hajduci, ali i profesionalni vojnici) tako i iz kulturnih razloga (osnova je narodna poezija); savremenost je crna u ekonomskom, kulturnom i političkom pogledu, a odgovornost se čas traži u spoljašnjem faktoru, čas u mentalitetu samog naroda; nadomestak takvoj savremenosti su prirodne lepote, oličene u slikama krajolika i opredeljenju za tekstove koje te slike živo opisuju; nadomestak je takođe „rasni“ momenat koji pojedini autori - pre svega Korolija i Desnica - nalaze u narodu. Konačno, emocija koja boji određeni broj tekstova jeste optimizam, što je eminentno politički gest, ali i patetični gest iskrene ljudske nade da će stvari poći na bolje, odnosno suprotno od poznatog Murphyjevog zakona: If anything can go wrong, it will (Ako nešto može poći nagore, poći će). U pozadini čitavog časopisa je ideja da intelektualci ne budu odvojeni od svoje sredine, već da joj posvete dužnu pažnju radi razvoja njene samosvesti i nastojanja ka opštem boljitku. Naravno, ispostavlja se da je i ovaj stav načelan, a poznato je i koliko je složena diskusija o vezama intelektualaca i naroda - setimo se samo Gramscijevih radova ili novije Rancièrove kritike ove u osnovi elitističke pozicije. Narod je nesumnjivo podređen, a Magazin Sjeverne Dalmacije pokušava - reklo bi se da na trenutke i uspeva - da govori u njegovo ime, premda nedovoljno problematizuje način na koji subalterni mogu i treba da govore. Činjenica je da se u časopisu, upr-

\footnotetext{
Vincent Kaufmann, Poétiques des groupes littéraires (avant-gardes 1920-1970), Paris 1997., 3.

9 William Marx, „The 20th Century: Century of the Arrière-Gardes?", Europa! Europa? The Avant-Garde, Modernism and the Fate of the Continent (ur. Sascha Bru i dr.), Berlin 2009., 65.
} 
kos njegovom zalaganju za egalitarnost, povremeno oseća elitistički prizvuk - bilo da je reč o ekonomskom ili znanstvenom elitizmu.

Jedan od važnih junaka magazina je Mirko Korolija (1886-1934). Pisac je prerano preminuo između objavljivanja prvog i drugog broja: časopis sadrži njegove pesme, putopis, deo drame, kao i njemu posvećen ogled samog Vladana Desnice. Korolija je bio pisac koji je niz svojih tekstova posvetio Severnoj Dalmaciji, često praćenih notom optimizma, koji je lice jednog političkog, ali i ljudskog sna:

Čim smo, dolazeći od mora, ili preko Hrvatske i Bosne, zašli u sivi krš i kamenjar Severne Dalmacije, u takozvanu dalmatinsku Zagoru, mi smo dobili impresiju kao da smo zašli u kraj i carstvo one male Pepeljuge iz priče. Možda i u predeo, gde se je ista ta priča o Pepeljuzi začela, ili gde se ona svaki dan iznova rađa. Jer, na koncu, sva ta Severna Dalmacija i nije drugo bila i nije drugo danas, nego jedna lepa, zdrava, pametna i bistra mala Pepeljugica, čije zbitije i sreća ima da se razvije. ${ }^{10}$

Iako ovaj citat ne potiče iz teksta objavljenog u Magazinu, on dobro oslikava i jednu važnu ideološku nit čitavog poduhvata. Ovo nas vraća temi dualizma, odnosno rascepa o kojoj sam govorio na početku. Reč je zaista o dubinskom mehanizmu - to postaje jasno kada se pročita početak Desničinog teksta o Koroliji. Dalmacija je ovde shvaćena kao prostor koji sjedinjuje velike, nepomirljive ili teško pomirljive razlike, a naročito „različite istorijske udese“. To je zemlja „(...) gdje raste i oleander i grab; gdje uz obalu u maistralu leprša dašak romanskog duha i vije se laka zapadna melopeja, a po zaleđu u buri struji duboko rasni narodni život i gudi primitivni monokord ". ${ }^{11}$ Iako se ovaj odlomak često navodi, malo se tumači, pa je potrebno zastati na trenutak i obratiti pažnju na dve važne reči, tipične za međuratno razdoblje: to su reči rasa (u sintagmi „rasni narodni život“ i primitivno (u sintagmi „primitivni monokord“). Za razliku od vremena pre Drugog svetskog rata, ove reči danas nemaju pozitivno značenje, pa je objašnjenje tim važnije.

Diskurs primitivizma lako je objasniti. On ovde ima utopijsku dimenziju i oslanja se na Rousseauovo poimanje plemenitog divljaka: iako u podređenom položaju, primitivac, plemeniti divljak je moralno čistiji, prirodniji i, moglo bi se reći, ljudskiji od ostalog čovečanstva, jer nije izložen uticaju zapadne civilizacije. Naravno, Rousseauova revolucija, oslonjena na Montaigneov esej o kanibalima, odnosi se na smeštanje prirodnog, primitivnog čoveka u prirodno stanje, koje nije prosto kultura divljaka, već idealno, nužno hipotetičko prirodno stanje - a zapravo povlašćeno heurističko sredstvo kritike civilizovanog stanja. Desnica jeste sklon takvoj kritici, ali moramo voditi računa da ona podrazumeva određenu estetizaciju i depolitizaciju subjekata koje želi da prikaže kao primitivne.

Upotreba reči rasa je opravdano postala inkriminisana nakon što su je se dočepali nacisti, ali je bila jedna od čestih reči u diskursima o društvima i narodima pre Drugog svetskog rata. Ova reč dolazi iz franuskog rečnika, kao što svedoči Renan u svom predavanju „Šta je narod?“ (na koje se oslanja i Uroš Desnica u jednom od tekstova u

\footnotetext{
10 Mirko Korolija, Izabrana dela, Beograd 1996., 483-484.

11 Magazin Sjeverne Dalmacije, 1/1934., 117.
} 
Magazinu Sjeverne Dalmacije): „U čemu se razlikuje načelo narodnosti od načela rase? Eto pitanja na kojem se zaustavlja duh, koji misli, da bio bio načisto sa samim sobom." ${ }^{12}$ Desnica (odnosno Desnice) se ovde javlja(ju) kao deo idejnog pokreta koji je nastao u Zapadnoj Evropi sredinom 18. i okončao se sredinom 20. stoleća (reč race se prvi put pojavila u francuskom jeziku 1648. godine). Cvetan Todorov je taj pokret umesno nazvao rasijalizam, želeći da razlikuje učenje od oblika ponašanja. ${ }^{13} \mathrm{U}$ takvoj upotrebi posebno je značajna uzajamna povezanost fizičkih, intelektualnih i moralnih karakteristika, jer se rasna podela istovremeno javlja kao oblik kulturne podele, a pojedinčevo ponašanje zavisi u velikoj meri od rasno-kulturne („etničke“) grupe kojoj pripada ${ }^{14}$ - što se sve zajedno smatralo „valjanom“ osnovom za raznolike oblike nacionalnih (ali i regionalnih) razlikovanja, karakterizacija i hijerarhizacija, jer upravo rasijalizam sa svojom prosvetiteljskom i scijentističkom pozadinom veruje u mogućnost donošenja univerzalnih sudova, u jedinstvenu hijerarhiju vrednosti, odnosno u jedan okvir za procenjivanje na osnovu kojeg se mogu donositi univerzalni sudovi. De Fontette tvrdi da je „rasijalizam“ bila zarazna navika epohe. ${ }^{15}$ To je značilo da je reč imala ogroman opseg značenja, a kulminaciju u Francuskoj je doživela 1937. i 1939. godine kada je III republika izdala poštanske marke sa natpisom: „Za spas rase...“

Razlike su prirodne, ali postoji opšti okvir za njihovu procenu - to je vera koja stoji iza ovakvog iskaza o rasi. Tipično za međuratno razdoblje, Desnica kao čovek kulture i regiona ipak se pozivao i na prirodne temelje izgradnje identiteta. $U$ tom pravcu vodi njegova teza da su upravo ti „primitivci“ (reč upotrebljena pozitivno) iz zaleđa izdržali „najljuća zla i najteža iskušenja“ i uspeli da očuvaju „nacionalni karakter ovom dijelu naše zemlje“. ${ }^{16}$ No put od relativno homogene etničke grupe do moderne nacije nije bio zajamčen, jer je to bilo protiv interesa velikih imperija, što vodi ka paradoksu diskursa prosvećenosti: „dok je u Evropi nacionalna svijest slavila trijumfe, ona je ovdje davljena u povojima“". ${ }^{17}$ Ali ova izvorna fraktura je dvostruka: taj isti Dinarac ostao je u svom krugu i upućen na sebe sama - paradoksalni individualista do kojeg nisu doprle vesti da je moderni individualizam nezamisliv bez koherentnog i formiranog društva. To je taj rascep, ukleštenost, unutar kojeg je tragao za svojim mestom Desnica. Kada je samosvest razvijena, kao što je bila kod njega, to postaje težak zadatak koji uzima u obzir sve moguće putanje i koji se pretvara u iscrpljivanje jezika i egzistencije kakvo ćemo čitati u njegovim kasnijim romanima.

$\mathrm{Na}$ koncu, kada je reč o estetičkim dimenzijama razmišljanja o dvojstvu, rekao bih da su ona postale snažne metafore, pokretači izlaganja jednog unutrašnjeg čoveka i uslov da se o svetu pripoveda iz neobične perspektive. Kada je, međutim, o njihovoj politici reč, možemo se složiti i ne složiti sa Desničinim stavovima, ali je mnogo važnije objasniti njihovo poreklo i postaviti ih u intelektualnu klimu međuratnog razdoblja. Potrebno je, na-

\footnotetext{
12 Ernest Renan, Šta je narod?, Beograd 1883., 12.

13 Tzvetan Todorov, Mi i drugi: francuska misao o ljudskoj raznolikosti, Beograd 1994., 99.

14 Isto, 100-101.

15 François de Fontette, Rasizam, Beograd 1999., 9.

16 Magazin Sjeverne Dalamcije, 1/1934., 117.

17 Isto.
} 
ime, objasniti želju da se ostvare ovakve nacionalne, regionalne, etničke karakterizacije, odnosno reputacije. Iako liberalni model insistira na autonomiji pojedinca, i iako je u današnje vreme teško odrediti šta bi to bile nacionalne karakteristike, razdoblje do Drugog svetskog rata je od toga pravilo nauku. Nije Desnica svakako bio deo glavnog toka takve nauke, poput Dvornikovića, ali jeste bio deo retorike koja je takvu nauku uslovila. Pa ipak, ispada da su te slike ostale važne za Desničinu verziju literarnog egzistencijalizma u Zimskom ljetovanju i u Proljećima Ivana Galeba upravo zato što su psihologizovane, produbljene i vraćene pojedincu, njegovim strahovima, njegovim nadama, htenjima i njegovom doživljaju sveta. To je samo još jedan argument koji ide u prilog njegovoj teoriji umetnosti iskrenosti („gola ljudska istina“) i nastojanja da se izrazi tačno ono što se htelo reći. Potrebno je u daljim naporima istraživati da li se, kako i u kojoj tački u Desničinom delu mire rasijalizam i estetizam, odnosno kako iz unutrašnjeg rascepa nastaje piščeva politika književnosti koja do dan-danas, kako se čini, uspeva da se spase od političkog posvajanja, što je istovremeno njena radost i njena kob.

\section{$\cos$}

\section{Magazin Sjeverne Dalmacije and Desnica's Politics of Literature: SOME REMARKS}

This paper looks into the deep connections between Desnica's editorial work in the journal Magazin Sjeverne Dalmacije and his literary work, particularly his novels Zimsko ljetovanje and Proljeća Ivana Galeba. Vladan Desnica's work is part of a disruptive experience, emanating from the modernist idea of literature and writing as a superior, higher form of existence, as well as from the fate brought about by being born in an area of geographical shifts, namely in Zadar, a town that found itself situated in several states during the 20th century. The fracture of light/dark, unknown/familiar, advanced/backward, the wish to use this duality to - through a strong self-awareness of its existence - expand existence and its meaning, is a wide phenomenon in Desnica's work, metastasizing in different directions. This must be taken into account while analyzing his editorial work in the Magazin Sjeverne Dalmacije, which was an attempt to construct a regional identity in the very stenuous circumstances of the 1930s. The organization of the journal was closer to the Enlightenment idea of "mapping" the world, than to the contemporary radical avant-garde journals present throughout Europan culture. Vladan Desnica could be found in the arrière-gardes camp, and we should use this angle - not only the angles of necessary or wilful political compromises to look at his editorial work. Above all, this labout must be contextualized in Desnica's politica of literarure (in the meaning used by Jacques Rancière), and not in an imaginary political history in which the writer knowingly played a minor role.

Keywords: the politics of literature, aestheticism, racism, regional identity, egalitarianism, elitism, arrière-gardes, duality 


\section{$\cos$}

\section{Literatura}

Vladan Desnica, Proljeća Ivana Galeba, u: Vladan Desnica (prir. Željko Milanović), Novi Sad 2013.

François de Fontette, Rasizam, Beograd 1999.

Dragan Jeremić, „Vladan Desnica“, Vladan Desnica (prir. Željko Milanović), Novi Sad 2013. 401-414.

Vincent Kaufmann, Poétiques des groupes littéraires (avant-gardes 1920-1970), Paris 1997.

Mirko Korolija, Izabrana dela, Beograd 1996.

Magazin Sjeverne Dalmacije, 1/1934.

Magazin Sjeverne Dalamcije, 2/1935.

William Marx, „The 20th Century: Century of the Arrière-Gardes?“, Europa! Europa? The AvantGarde, Modernism and the Fate of the Continent (ur. Sascha Bru i dr.), Berlin 2009., 59-71.

Jacques RANCIÈRE, Estezis: scene estetskog režima umetnosti, Novi Sad 2014.

Jacques RANCIÈRE, La parole muette: Essais sur les contradictions de la littérature, Paris 1998.

Jacques Rancière, Politika književnosti, Novi Sad 2008.

Ernest Renan, Šta je narod?, Beograd 1883.

Tzvetan Todorov, Mi i drugi: francuska misao o ljudskoj raznolikosti, Beograd 1994. 